\title{
Assessment of dietary protein supplementation on milk productivity of commercial organic dairy farms during the grazing season
}

\author{
A. Ayers, ${ }^{1}$ S. E. Ziegler, ${ }^{2} \oplus$ H. M. Darby, ${ }^{2} \oplus$ S. Bosworth, ${ }^{2}$ J. P. Alvez, ${ }^{3} \oplus$ J. Colby, ${ }^{3}$ J. Kraft, ${ }^{1} \odot$ \\ and S. L. Greenwood ${ }^{1 *}$ (1) \\ ${ }^{1}$ Department of Animal and Veterinary Sciences, University of Vermont, Burlington 05405 \\ ${ }^{2}$ University of Vermont Extension, University of Vermont, St. Albans 05478 \\ ${ }^{3}$ Center for Sustainable Agriculture, University of Vermont, Burlington 05405
}

\begin{abstract}
Variability of protein and energy supply from pasture during the grazing season is a primary factor that can influence milk production of grazing organic dairy herds in the Northeast United States. This study evaluated the effects of altering the crude protein $(\mathrm{CP})$ content of dietary supplements included in dairy rations fed to grazing organic dairy herds, on milk production and composition. Six commercial organic farms participated in a 6 -wk trial, consisting of a 2 -wk baseline period and 4 -wk experimental period. Farms were paired by their summer 2017 milk urea nitrogen profile, and farms within each pair were assigned by restricted randomization to (1) continuation of their regular supplements ( $\mathrm{n}=3$, control group, CON), or (2) supplement with altered CP as percentage of dry matter, formulated using an organic barley and roasted soybean mix ( $\mathrm{n}=$ 3 , treatment group, TRT). Throughout the 6 -wk trial, individual milk samples were collected at 2 consecutive milkings weekly, while pasture and supplement samples, pasture measurements, and management information were collected twice weekly per farm. Data were statistically analyzed using the MIXED procedure of SAS (version 9.4, SAS Institute Inc.) for all parameters, and effects of treatment, week, and their interaction (treatment $\times$ week) were determined. The supplement $\mathrm{CP}$ (percentage of dry matter) during the baseline period was $13.5 \%$ for CON and $15.3 \%$ for TRT and $14.8 \%$ for CON and $19.3 \%$ for TRT during the experimental period. Milk production was $21 \%$ higher during the experimental period for TRT compared with CON (24.1 vs. $19.9 \mathrm{~kg}$ of milk per day, respectively). Milk production decreased for CON from wk 1 to wk 6 (23.6 vs. $20.4 \mathrm{~kg}$ of milk per day), whereas TRT maintained milked production from wk 1 to wk 6 (22.8 vs. 22.7
\end{abstract}

Received February 23, 2021.

Accepted September 25, 2021.

*Corresponding author: sabrina.greenwood@uvm.edu $\mathrm{kg}$ of milk per day). Milk composition was different between groups, with CON having higher fat percent (4.21 vs. $3.73 \%$, respectively) and protein percent (3.15 vs. 3.05\%, respectively) compared with TRT for the 6 wk. The milk urea nitrogen concentrations were similar between TRT and CON for the baseline period (11.9 vs. $12.1 \mathrm{mg} / \mathrm{dL}$ ) and the final week of the experimental period (14.5 vs. $14.2 \mathrm{mg} / \mathrm{dL}$ ). Although the effects of different diet CP fractions, particularly rumen undegradable protein and soluble protein, must be further delineated, these results indicate that altering the $\mathrm{CP}$ content of dietary supplements fed to grazing organic dairy cattle during the summer period in the Northeast US could be a useful mechanism to maintain milk production.

Key words: pasture, Northeast, crude protein

\section{INTRODUCTION}

Since they first appeared in conventional supermarkets in the late 1990s, the demand for organically produced dairy products has increased and currently accounts for approximately $15 \%$ of the total organic market and approximately $6 \%$ of total US fluid milk sales (USDA ERS, 2002; USDA NASS, 2017). Providing organic dairy cattle with nutrient-dense diets that support milk production targets can be challenging in these organic systems, particularly due to the high reliance on forage growth and quality of the pasture-based diets that are required by the USDA organic regulations and the more limited supplement options permitted under these regulations (Hoogendoorn et al., 1992; USDA AMS, 2010b; Macoon et al., 2011). Although organic dairies require a higher pasture intake (at least $30 \%$ of daily DMI from pasture for a minimum of 120 d/yr; USDA AMS, 2010a), seasonal variations and fluctuating weather patterns during the grazing season in the Northeast United States can influence botanical composition, herbage mass, and nutrient quality of fresh forages available for grazing animals (Soder et al., 
2006; Hafla et al., 2014). Limitations in nutrient profiles of the pasture, particularly limitations in energy and $\mathrm{CP}$ during this period of slowed growth rate in the summer, can be partially mitigated through manipulation of the pasture botanical profile (e.g., Ritz et al., 2020) or through alteration of the dietary supplement profile. Adjusting the supplement to create a nutritive profile that is complementary to the pasture can provide a practical means to increase nutrient uptake and productivity of cattle during the grazing season.

Supplements for organic dairy farms are commonly used to supply these nutrients, particularly energy and rumen undegradable protein, and are formulated with molasses, beet pulp, barley, wheat, rapeseed, or soybean. Various studies have evaluated the effects of these ingredients on animal performance (Bargo et al., 2003; Hardie et al., 2014; Liang et al., 2017). Inclusion of supplements appears to consistently improve productivity, regardless of base pasture species. Adding in starch- (e.g., oats, barley, corn meal) or fiber-based feedstuffs (e.g., wheat middlings, wheat bran) consistently improves milk productivity of cows grazing grass (e.g., Khalili and Sairanen, 2000) and grass + legume pastures (e.g., Higgs et al., 2013). Inclusion of ingredient combinations to customize the nutritive profile of the supplement, as opposed to offering a singular ingredient to bolster energy uptake, also appears to further increase production responses (Khalili and Sairanen, 2000; Nikkhah, 2012; Soder et al., 2012), suggesting that multi-ingredient supplements should be further considered. Additionally, including protein-dense feedstuffs in the formulated supplement (e.g., Mogensen et al., 2008) may increase productivity of pasture-based cows, particularly in the Northeast, where both energy and $\mathrm{CP}$ are often limiting production (Hafla et al., 2016). Together, this suggests relevance in further exploring potential effects of feedstuff combinations and nutritive profiles of supplements offered to grazing cows in the Northeast.

Although assessment of energy and protein uptake is difficult in a pasture setting, one method to indirectly assess dietary $\mathrm{CP}$ intake of grazing cows is through measurement of MUN concentrations in milk. Ideal MUN concentrations are between 8.00 and $12.0 \mathrm{mg} / \mathrm{dL}$, whereas concentrations below $8 \mathrm{mg} / \mathrm{dL}$ may indicate limited protein availability (Nousiainen et al., 2004) and above $12 \mathrm{mg} / \mathrm{dL}$ may signify excess ration protein with higher environmental nitrogen loss and can possibly result in reproductive issues (Kohn et al., 2002; Aguilar et al., 2012; Correa-Luna et al., 2020). Studies observing MUN concentrations in grazing dairy cows conducted in Australia, Finland, and Sweden have all indicated variations in MUN concentrations ranging from 3.80 to $40.3 \mathrm{mg} / \mathrm{dL}$ in grazing animals (Trevaskis and Fulker- son, 1999; Nousiainen et al., 2004). Concentrations of MUN have also been observed to vary throughout the grazing season, as energy-to-protein ratios can vary in pasture (Moller et al., 1993; Godden et al., 2001). A previous study conducted in Vermont during the 2017 grazing season identified variable MUN concentrations in grazing organic dairy farms across the state of Vermont, with concentrations ranging from 5.36 to 14.7 $\mathrm{mg} / \mathrm{dL}$ (Ayers, 2020). Previous research suggests that cows producing MUN concentrations around $14 \mathrm{mg} / \mathrm{dL}$ will not likely suffer with regard to production, but cows at the lower end of the measured range $(\sim 5.4 \mathrm{mg} / \mathrm{dL})$ may have lower productivity (Nousiainen et al., 2004; Powell et al., 2011). The variability of measured MUN reported by Ayers (2020) also further supports the hypothesis that protein intake during the grazing season in the northeastern state of Vermont is inconsistent and may not be optimal. Implementing use of a moderate protein supplement on farm that is complementary to typical Vermont pasture profiles could modulate protein excretion in the region, ultimately reducing excess nitrogen losses from herds consuming higher-protein grass + legume pastures while improving nitrogen availability to cows grazing lower-protein grass + legume pastures. Assuming that the low MUN concentrations observed in milk from organic dairies during the 2017 grazing season as outlined by Ayers (2020) accurately reflect a protein deficiency, these MUN profiles suggest that altering the dietary protein profile could improve cow performance. Therefore, our hypothesis was that feeding a supplement with a moderate $\mathrm{CP}$ concentration (target of $16 \%$ of $\mathrm{DM}$ ) to grazing organic dairy herds in Vermont can improve milk production and MUN profiles by providing nutrients limited by pasture during the grazing season. The objective of this study was to evaluate the effects of altering dietary $\mathrm{CP}$ offered in dairy rations on individual MUN profile, milk yield, and milk composition produced by grazing dairy cattle housed on commercial organic dairies during the summer in Vermont.

\section{MATERIALS AND METHODS}

Animal use and sampling methods performed in this trial were reviewed and approved by the Institutional Animal Care and Use Committee of the University of Vermont (protocol no. 16-022; Burlington, VT) in accordance with the requirements of the Office of Laboratory Animal Welfare.

\section{Experimental Design}

Six commercial Vermont organic dairy farms (54.0 \pm 2.6 lactating cattle per farm) participated in a 6 -wk 
trial (June to August 2018). Statistical power and farm number selection were based on herd size and anticipated change in MUN: to detect a $5 \%$ difference in MUN $(\mathrm{mg} / \mathrm{dL})$ between control and treatment animals, and assuming an $18 \%$ coefficient of variation (calculated using SD and mean MUN calculated from milk data collected from 16 Vermont organic dairy farms participating in research the previous summer; Ayers, 2020), 205 animal replicates were needed for experiments of $80 \%$ power at $P<0.05$. Historic herd size data were used to identify how many farms would be needed to meet this replicate number. Farms were selected based on their diet management practices and diet nutrient profiles recorded in a previous research study with the University of Vermont (Ayers, 2020). Criteria for participation were as follows: twice-daily milking, USDA organic certification, herd size greater than 20 lactating cows, and year-round freshening. A complete block design was used, and farms were paired by researchers based on their summer 2017 MUN profiles (mean: 10.9 $\pm 3.5 \mathrm{mg} / \mathrm{dL}$; Table 1 lists simple individual farm-level MUN concentrations used for blocking), and restricted randomization was used to assign farms to 1 of 2 treatment groups within each pair. Restricted randomization was used to block farms into pairs and balance preexperiment diet $\mathrm{CP}$ content across treatment groups and thus minimize experimental bias due to pre-experimental diet CP content. No additional restrictions were applied. Farms within pair were then stratified across treatments and assigned to 1 of 2 treatments. Pivot tables were created to confirm balanced treatment assignment based on previous herd MUN concentration $(\mathrm{mg} / \mathrm{dL})$, milking herd size (number of cows), grain fed $(\mathrm{kg} / \mathrm{cow}$ per day), and milk production $(\mathrm{kg} / \mathrm{cow}$ per day). Blinding was not used. The trial consisted of a 2-wk baseline period, where all herds continued with their routine management and feeding strategies, followed by a 4 -wk experimental period, where farms within each pair were assigned to either (1) continuation of their routine diet supplement and management plan throughout the experimental period $(\mathrm{n}=3, \mathbf{C O N})$ or (2) replacement of their diet supplement with a protein-rich supplement but maintained on their regular management strategies $(\mathrm{n}=3$, TRT $)$. All TRT supplements were custom formulated (using CFD Nutrition software, Co-operative Feed Dealers Inc.; formulated in collaboration with Morrison's Custom Feeds, Barnet, VT) to complement typical Northeast pasture profiles and create nutritionally balanced complete diets based on typical Northeast grazing herd requirements as well as previous supplement formulations used on each individual TRT farm to meet individual herd requirements. It was presumed, for both the baseline and the experimental period supplements used by the CON and
TRT groups throughout the trial, that the supplements fed in combination with the pasture would meet cow nutrient requirements and create a nutritionally balanced total diet, but this was not specifically validated at the individual farm level before commencement of the trial. To alter $\mathrm{CP}$ (as percentage of $\mathrm{DM}$ ) of the supplement, organic wheat middlings, barley, roasted soybean, molasses and steam flaked corn proportions were altered in the supplement being fed on the 3 TRT farms during the experimental period to target a $16 \%$ CP supplement. All other microingredients (e.g., organic minerals, vitamins, and additives) were adjusted to nutritionally balance the diet as needed during the original formulation, but ingredients typically included in each farm's ration were not removed, to reduce confounding effects of ingredient changes. Mean supplement ingredient profile as a percent of weight $( \pm \mathrm{SE})$ was as follows: organic wheat middlings, $18.0 \pm 0.0$; organic barley, $44.8 \pm 2.9$; organic roasted soybean, $24.6 \pm 0.1$; organic molasses, $2.1 \pm 0.1$; organic steam flaked corn, $3.3 \pm 3.3$; micronutrients, $7.1 \pm 0.3$. This TRT supplement formulation was completed before the start of the trial.

Custom TRT supplements were transported to the respective TRT farms during the baseline period (farms received whatever tonnage the farm could appropriately store, with reoccurring tonnage being transported to the individual farms as needed), and cows on the TRT farms were switched to their TRT supplement from their typical supplement at the end of the baseline period, so that cows started receiving their new TRT supplements during wk 3 of the trial (the first week of the experimental period). The TRT supplement formulations were not adjusted during the trial to reflect any changes in pasture composition, and any changes in chemical composition of the supplement were a result of changes in ingredient nutritive profiles. The CON farms continued to receive their typical supplements as per their own schedules and needs for the duration of the trial.

Sampling and data collection for each experiment parameter occurred on each farm weekly throughout the $6 \mathrm{wk}$, with sampling techniques and analysis protocols for each parameter outlined herein.

\section{Management Information}

Management data were provided by the producer and recorded weekly, including grazing protocol, feeding protocol, and herd demographics. Number of animals grazing in the paddock, including lactating animals, dry cows, heifers, or bulls, was recorded. Hours per day the animals had access to pasture were estimated by the producer and recorded. Amount of supplement, 
Ayers et al.: GRAZING CATTLE AND DIETARY CRUDE PROTEIN

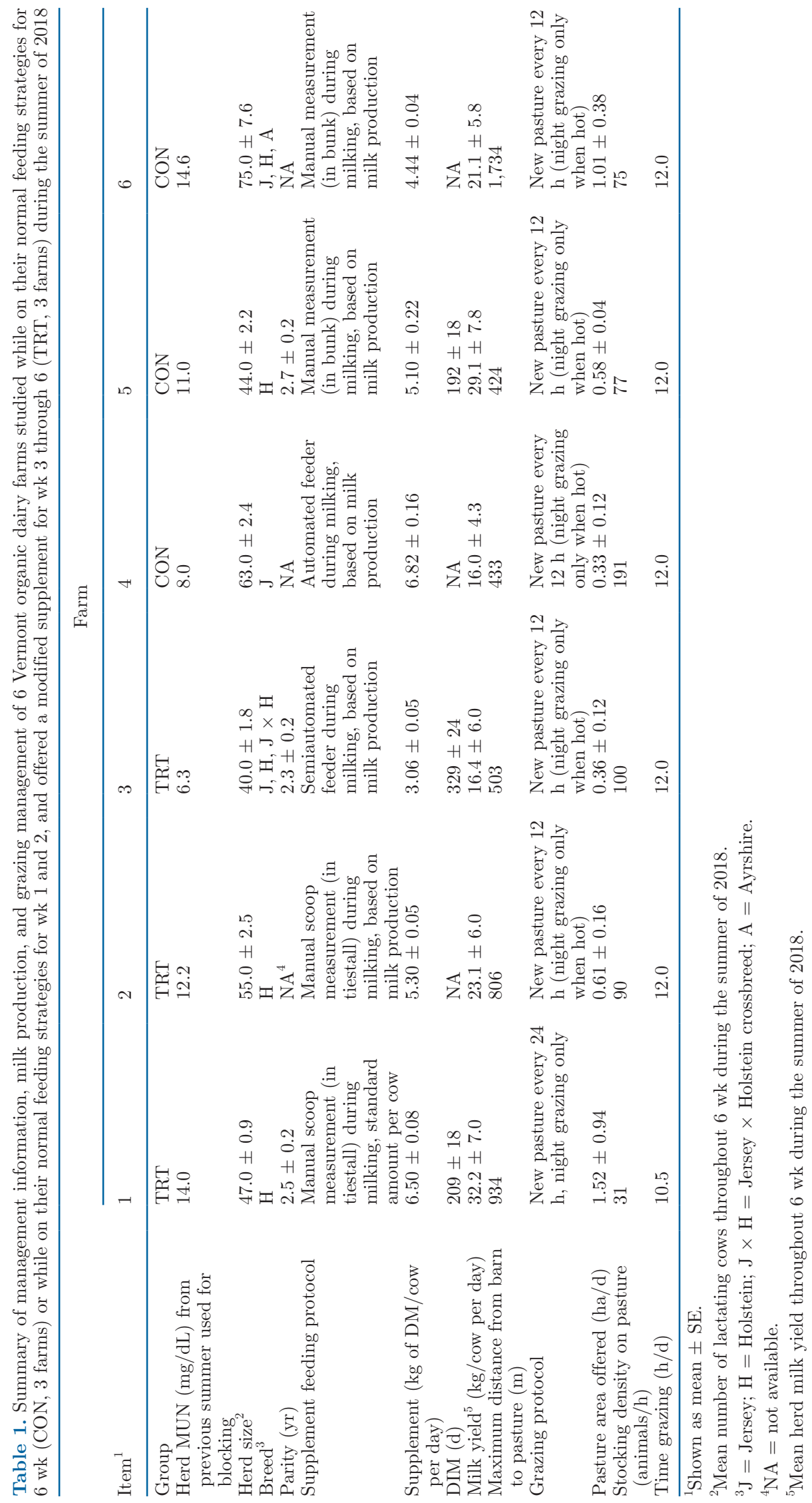


including concentrates and conserved forages, was estimated by the producer and recorded. Changes in any management or grazing protocol that occurred during the $6 \mathrm{wk}$, as stated by the producer, was recorded. The total rainfall, mean temperature, maximum temperature, and minimum temperature for the baseline and experimental periods for the counties in which the CON and TRT groups were located were recorded using climate monitoring software through the National Centers for Environmental Information (National Oceanic and Atmospheric Administration, Climate at a Glance, County Time Series, https://www.ncdc.noaa .gov/cag/).

\section{Animal Information}

Assessment of BCS (scale 1 to 5 , where 1 indicates severe undercondition and 5 indicates severe overcondition; Wildman et al., 1982) was performed and recorded weekly by 2 independent, trained project personnel for up to 50 lactating cows per herd, and the mean of these scores across personnel within cow within week was included in statistical analysis.

Individual milk yields were recorded for each cow at each farm for 2 consecutive milkings weekly throughout the 6 -wk trial. Milk samples were collected from each cow at each of the 2 milkings per week using in-line samplers. Samples were collected in vials with bronopol preservative, and analyzed commercially (DairyOne, Ithaca, NY; Lancaster DHIA, Manheim, PA) for fat percent, protein percent, and MUN concentration using Fourier-transform infrared spectroscopy technology (FOSS FTIR MilkoScan).

\section{Non-Pasture Feed Supplement Sampling}

Grab samples of supplements were collected from each farm weekly, along with samples of any conserved forage offered. Feed samples were frozen to $-20^{\circ} \mathrm{C}$ on the day of collection, then subsequently thawed and commercially analyzed through wet chemistry analysis using traditional AOAC methods (DairyOne, Ithaca, $\mathrm{NY}$ ) to determine DM and nutritive profile. Refusals were measured when available, if the supplement offered was not completely eaten or removed by producers before researchers arrived on farm. Refusals were measured by collection of all feedstuff left over after feeding in a measured area, weighing the collected refusals using portable scales, and multiplying the refusal weight of the measured area by the entire feeding area. This estimated refusal was then subtracted from the producer-estimated supplement mass offered, to achieve an estimate of supplement intake per day per animal.

\section{Pasture Mass, Disappearance, and Dry Matter Intake}

Pasture measurements were collected weekly on each farm on 2 consecutive days concurrent with milking samplings at each farm. At the time of sampling, paddocks that were grazed most recently were measured to determine postgrazing pasture mass, and paddocks that were to be grazed next were measured to determine pregrazing pasture mass, botanical composition, and nutritional composition. Areas and dimensions of paddocks were determined using a distance wheel and verified using the parameter tool on Google Earth software (Google Earth Pro, version 7.3, accessed 2018) for individual farms. The herbage mass of each paddock was estimated using a rising plate meter (Jenquip), with approximately 50 measurements taken in a diagonal pattern across each paddock. Weekly, quadrat cuts $\left(1 \mathrm{~m}^{2}\right)$ were taken in both pre- and post-grazed pastures at areas that were visually identified as being low, medium, and high grass heights (15 samples per farm per visit). The measured quadrat areas were selected at random, rising plate meter measurements were taken at the randomly selected site, and all forage material in the quadrat was cut to ground level and collected. Forage material was transported at ambient temperature to the University of Vermont Horticulture Research Center (South Burlington, VT). Upon arrival, materials from each of the quadrat samples were weighed and then oven-dried for up to $48 \mathrm{~h}$ at $55^{\circ} \mathrm{C}$ and reweighed. To calibrate the rising plate meters and take into account changes in pasture throughout the trial, pasture quadrat cuts collected across the 6 -wk experiment were used to generate a calibration curve. The measurements collected on wk 1,3 , and 5 of the trial were used to create an individualized calibration curve within each farm. Rising plate meter measurements within farm were applied to the individualized slope equation of the calibration curve to estimate pasture disappearance for individual farms. Pasture disappearance was determined by subtracting the estimated mass of the post-grazed pasture area from the estimated mass of the pre-grazed pasture area. Pasture DMI of cows was estimated by dividing the number of cows grazing by the calculated pasture disappearance.

\section{Pasture Botanical and Chemical Profiles}

During sample collection each week, representative pasture samples were hand-cut (approximately $50 \mathrm{~g}$ ) to an estimated grazing height by visually examining the height of the post-grazed paddock, collected at even intervals, collecting approximately 10 to 15 samples diagonally across the paddock. These samples were then 
pooled as previously described by Totty et al. (2013). Samples were transported at ambient temperature to the University of Vermont Horticulture Research Center (South Burlington, VT). Two representative subsamples were then used for further analysis. One of the representative subsamples from the pooled sample was hand sorted into 4 botanical fractions: legumes, weed, grass, and dead material. After the fresh weight of each botanical fraction was taken, all components were oven-dried at $55^{\circ} \mathrm{C}$ for up to $48 \mathrm{~h}$ to determine the botanical profile of the pre-grazed pasture on a DM basis. To determine the nutritive profile of the pre-grazed pasture, the second representative subsample was taken from the pooled sample, weighed fresh, oven-dried at $55^{\circ} \mathrm{C}$ for up to $48 \mathrm{~h}$, and reweighed. This subsample was then ground to $1 \mathrm{~mm}$ using a Wiley Mill (Thomas Scientific), and analyzed using near-infrared reflectance spectroscopy (FOSS NIRS DS2500, MN; University of Vermont Agriculture Testing, Burlington, VT) with 2016 NIRS Consortium calibrations (https://www .nirsconsortium.com) to determine levels of water-soluble carbohydrates, ADF, ash-free NDF (aNDFom), $\mathrm{CP}$, ash, minerals, and fat.

\section{Statistical Analysis}

Parameters were analyzed using the MIXED procedure of SAS version 9.4 (SAS Institute Inc.). The effect of group (CON vs. TRT), week, and group $\times$ week on milk production (yield and composition), BCS, pasture parameters (disappearance, DMI, pre- and postgrazing mass, botanical composition, and chemical profile) were determined using the LSMEANS option for procedures including week as the repeated measure. An unstructured covariate structure was selected as the covariance structure on the basis of best fit according to Bayesian information criterion. Statistical significance was declared if $P<0.05$.

\section{RESULTS}

\section{Management Practices}

Management information is summarized in Table 1. The mean time spent on pasture, as reported by producers, for both TRT and CON groups was $11.8 \pm 0.3$ $\mathrm{h}( \pm \mathrm{SE})$ throughout a 24 -h period. Mean pasture area offered per day was $0.74 \pm 0.19$ ha for the TRT group and $0.64 \pm 0.20$ ha for the CON group $( \pm \mathrm{SE}$ ), and farms in both groups used rotational grazing practices. Weather data for the home counties of participating farms is summarized in Table 2. Historic temperature and precipitation information is also listed in Table 2 for reference. Across all of these counties during the trial, the mean temperature $( \pm \mathrm{SD})$ was $18.4 \pm 0.7^{\circ} \mathrm{C}$, the mean maximum temperature was $25.5 \pm 1.2^{\circ} \mathrm{C}$, and the mean minimum temperature was $11.5 \pm 0.6^{\circ} \mathrm{C}$ for the baseline period. For the experimental period, the mean temperature $( \pm \mathrm{SD})$ was $20.8 \pm 0.9^{\circ} \mathrm{C}$, the mean maximum temperature was $27.3 \pm 1.4^{\circ} \mathrm{C}$, and the mean minimum temperature was $15.1 \pm 1.7^{\circ} \mathrm{C}$ across all the counties recorded. The total rainfall $( \pm \mathrm{SD})$ within the counties was $10.6 \pm 1.8 \mathrm{~cm}$ for the baseline period and $10.8 \pm 3.4 \mathrm{~cm}$ for the experimental period.

\section{Supplement Feed Information}

Weekly nutrient composition analysis of the CON and TRT diet supplements are listed in Table 3. The ingredients included in the formulated supplement had a higher $\mathrm{CP}$ concentration than formulated (original target for TRT was $16 \% \mathrm{CP}$ ); the final supplement CP percentage fed during the experimental period of the trial was $14.8 \%$ (percent of DM) for the CON group and $19.3 \% \mathrm{CP}$ (percent of DM) for the TRT group. As a percentage of $\mathrm{CP}$, soluble protein was higher in the supplement provided on the CON farms compared

Table 2. Total rainfall and mean, minimum (min), and maximum (max) temperatures of counties in which 6 Vermont organic dairy farms were located and studied while on their normal feeding strategies for 6 wk (CON, 3 farms) or while on their normal feeding strategies for wk 1 and 2 (baseline period) and offered a modified supplement for wk 3 through 6 (TRT, 3 farms; experimental period) during the summer of 2018

\begin{tabular}{|c|c|c|c|c|c|c|c|c|c|c|}
\hline \multirow[b]{2}{*}{ County } & \multirow{2}{*}{$\begin{array}{l}\text { Historic July } \\
\text { rainfall }^{1}\end{array}$} & \multirow{2}{*}{$\begin{array}{l}\text { Historic mean } \\
\text { July temperature }\end{array}$} & \multicolumn{4}{|c|}{ Baseline $^{3}$} & \multicolumn{4}{|c|}{ Experimental $^{4}$} \\
\hline & & & Mean & Max & Min & Rainfall & Mean & Max & Min & Rainfall \\
\hline Orleans & 11.3 & 18.3 & 18.8 & 25.4 & 12.2 & 12.5 & 21.1 & 27.3 & 14.9 & 11.5 \\
\hline Windham & 10.5 & 19.0 & 18.7 & 25.6 & 11.9 & 12.4 & 21.0 & 27.1 & 17.9 & 16.1 \\
\hline Franklin & 11.1 & 19.6 & 18.9 & 27.1 & 10.8 & 9.04 & 21.7 & 29.2 & 14.1 & 7.60 \\
\hline Addison & 10.0 & 19.7 & 17.3 & 23.7 & 10.9 & 8.56 & 19.4 & 25.4 & 13.4 & 8.05 \\
\hline
\end{tabular}

${ }^{1}$ Historic July rainfall (cm) within county from 1901 to 2000 (NOAA, National Centers for Environmental Information, 2019).

${ }^{2}$ Historic mean July temperature $\left({ }^{\circ} \mathrm{C}\right)$ within county from 1901 to 2000 (NOAA, National Centers for Environmental Information, 2019).

${ }^{3}$ Baseline period $=$ wk 1 and 2 . Mean temperature $\left({ }^{\circ} \mathrm{C}\right)$ within the county. Total rainfall $(\mathrm{cm})$ within the county.

${ }^{4}$ Experimental period $=$ wk $3-6$. Mean temperature $\left({ }^{\circ} \mathrm{C}\right)$ within the county. Total rainfall $(\mathrm{cm})$ within the county. 
with the TRT farms during the baseline period (20.3 vs. $16.3 \%$ of $\mathrm{CP}$, respectively), and the disparity grew during the experimental period (soluble protein $26.2 \mathrm{vs.}$ $15.3 \%$ of $\mathrm{CP}$ for CON and TRT farms, respectively). This disparity was largely a result a shifting supplement soluble protein in the CON farm supplements (as percent of CP; Table 3). Differences in the ADF, aNDFom, and mineral content across the TRT and CON supplements were presumed to be a result of custom formulation.

\section{Milk Yield and Composition}

Milk production and composition for both TRT and CON are summarized in Table 4 and Figures 1 and 2 . Milk yield was affected by group $(P=0.001)$, week $(P<0.0001)$, and the group by week interaction $(P$ $<0.0001)$. During the baseline period, TRT and CON had similar milk yields (22.6 vs. $22.4 \mathrm{~kg}$ of milk per day). The TRT group had a higher milk yield during the duration of the experimental period compared with the CON group (23.6 vs. $20.7 \mathrm{~kg} / \mathrm{d}$, respectively). Milk fat percent was affected by group $(P<0.0001)$, week $(P<0.0001)$, and group by week interaction $(P<$ 0.0001). Milk protein percent was affected by group $(P=0.0049)$, week $(P<0.0001)$, and group by week interaction $(P<0.0001)$. Milk fat and protein percent were higher for CON during the duration of the trial compared with TRT (4.21 vs. $3.73 \%$ fat and 3.14 vs. $3.04 \%$ protein, respectively). Mean MUN concentrations were affected by group $(P<0.0001)$, week $(P<$ $0.0001)$, and group by week interaction $(P<0.0001)$. The MUN concentrations (Figure 3) were similar for TRT and CON during the baseline period (11.9 and $12.1 \mathrm{mg} / \mathrm{dL}$ ), and higher than the previous season for both groups. The MUN concentrations were also similar between TRT and CON during wk 6 (14.5 vs. 14.2 $\mathrm{mg} / \mathrm{dL}$ ); however, TRT increased from wk 3 to wk 6 (12.6 vs. $14.5 \mathrm{mg} / \mathrm{dL})$, whereas CON decreased from wk 2 to wk 5 (13.6 vs. $10.6 \mathrm{mg} / \mathrm{dL})$ and then increased from wk 5 to wk 6 (10.6 vs. $14.2 \mathrm{mg} / \mathrm{dL})$.

\section{Animal Information}

Weekly BCS recorded by the evaluators is summarized in Table 4 . We found a difference in mean BCS between TRT and CON groups $(P=0.02)$ between weeks, and a treatment by week interaction was observed $(P<0.0001)$. The initial BCS recorded in wk 1 and final BCS recorded in wk 6 for TRT $( \pm$ SE) were $2.61 \pm 0.03$ and $2.69 \pm 0.02$, respectively, whereas the initial and final BCS for CON were $2.65 \pm 0.03$ and $2.79 \pm 0.03$, respectively, based on the 5 -point scale.

\section{Pasture Composition, Mass, and Dry Matter Intake}

Pregrazing pasture mass was $3,587 \mathrm{~kg}$ of DM per hectare, and postgrazing pasture mass was $2,869 \mathrm{~kg}$ of DM per hectare for CON and TRT. Estimated DMI for CON and TRT was $7.87 \mathrm{~kg} / \mathrm{d}$; however, this varied throughout the weeks, as shown in Table 5 .

Botanical composition is summarized in Table 6 . Botanical composition was similar for both TRT and CON for baseline and experimental periods, with the composition of weeds significantly decreasing during the experimental period $(P<0.05)$. During the baseline period, the botanical composition was approximately $53 \%$ grass, $11 \%$ legume, $26 \%$ forbs, and $10 \%$ dead material. During the experimental period, the botanical composition was approximately $68 \%$ grass, $18 \%$ legume, $8 \%$ forbs, and $6 \%$ dead material. Nutrient composition varied throughout the $6 \mathrm{wk}$; however, we found no difference in nutrient composition of pasture between CON and TRT and no group by week interaction for the nutritional profile. The aNDFom, $\mathrm{Ca}$, fructan, and lignin concentrations in pastures varied throughout the weeks within both TRT and CON pastures $(P<$ 0.05; Table 7); however, these data were within normal reported ranges for pastures in the Northeast (Soder et al., 2006; Hafla et al., 2014).

\section{DISCUSSION}

This study sought to evaluate the effects of altering dietary $\mathrm{CP}$ content fed to grazing organic dairy cows on milk production, milk composition, and MUN profile. The commercial farms that participated in this study were located within the state of Vermont and had MUN concentrations ranging from 5.4 to $14.7 \mathrm{mg} /$ $\mathrm{dL}$ during the previous summer grazing season, with many individual animals having MUN concentrations below $8.00 \mathrm{mg} / \mathrm{dL}$, indicating that dietary protein could potentially be limiting (Oltner and Wiktorsson, 1983; Trevaskis and Fulkerson, 1999; Godden et al., 2001; Powell et al., 2014). Our hypothesis was that altering the dietary $\mathrm{CP}$ levels in supplements offered to these animals could improve MUN concentrations and milk production, giving organic producers in the Northeast a strategy to overcome nutrient limitations in the pasture during the grazing season. Limitations in pasture energy concentration (e.g., Hafla et al., 2016) and, to a lesser extent, rumen undegradable protein concentration (e.g., Mogensen et al., 2008) are particular challenges facing grazing operations, with the Northeast being no exception. Although our main hypothesis centered around the idea that $\mathrm{CP}$, not specifically rumen-degradable or undegradable protein, 


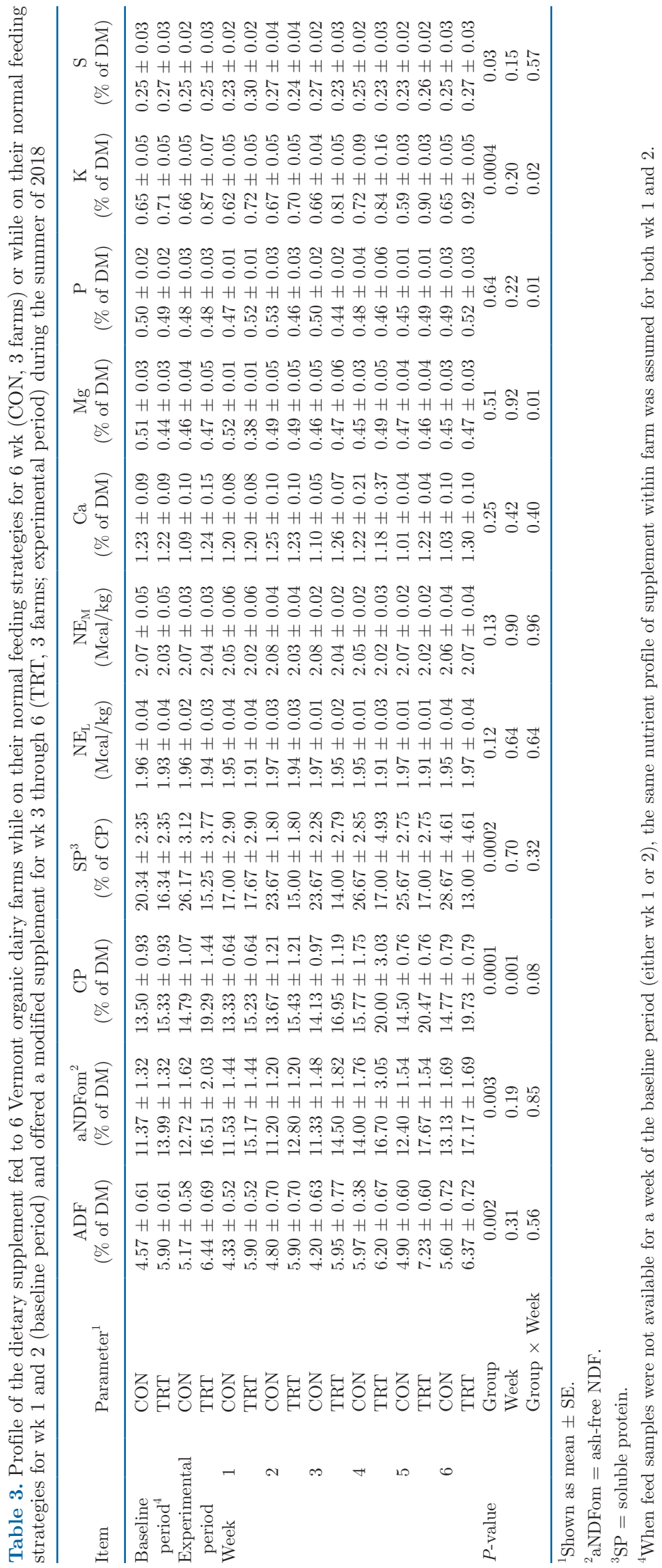


Ayers et al.: GRAZING CATTLE AND DIETARY CRUDE PROTEIN

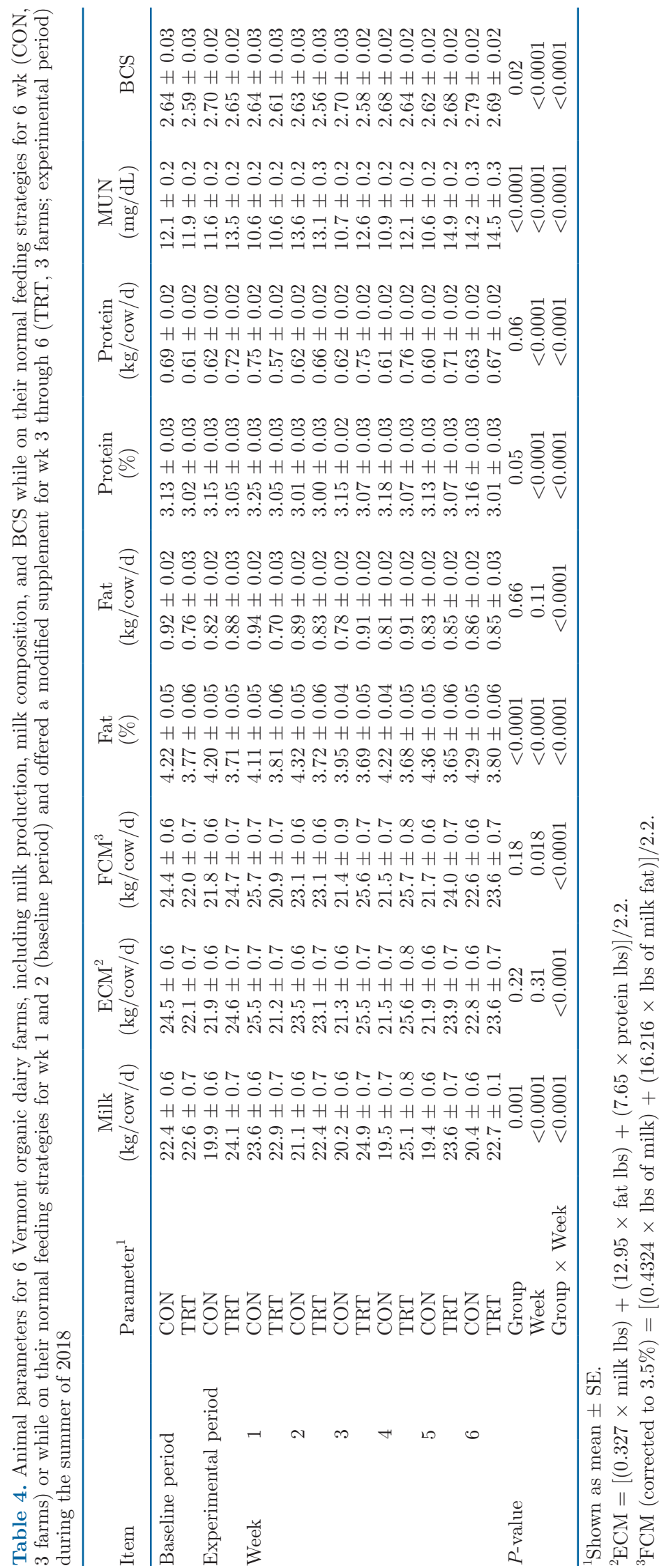




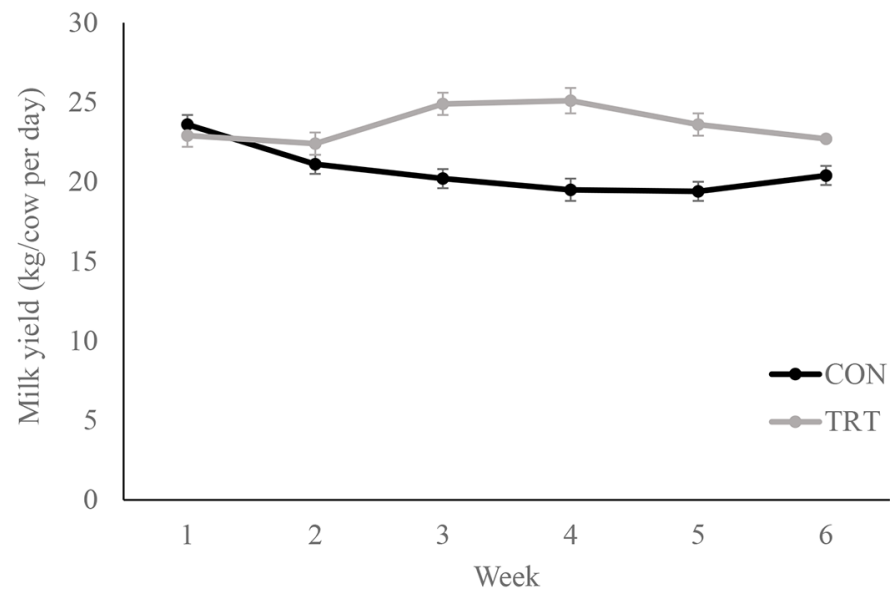

Figure 1. Mean weekly milk yield $( \pm \mathrm{SE})$ of 6 Vermont organic dairy farms while on their normal feeding strategies for $6 \mathrm{wk}(\mathrm{CON}, 3$ farms) or while on their normal feeding strategies for wk 1 and 2 and offered a modified supplement for wk 3 through 6 (TRT, 3 farms). Milk yield was affected by group $(P=0.001)$, week $(P<0.0001)$, and group $\times$ week $(P<0.0001)$.

would improve performance of grazing dairy cows in the Northeast, several considerations regarding the $\mathrm{CP}$ profile of the supplements provided in the current trial support previous research suggesting that protein fraction may be the more critical factor. First, it must be acknowledged that we did manipulate ingredients, such as roasted soybean, that typically have higher-quality rumen undegradable protein, to adjust the total $\mathrm{CP}$ (as a percentage of DM). Second, likely due to some unknown changes in individual feedstuff qualities and profiles, the experimental period TRT supplement was of a higher $\mathrm{CP}$ percentage $(19.3 \% \mathrm{CP})$ than originally targeted, particularly during the latter part of the experimental period, and this higher CP percentage of the TRT supplement was consistent across all of the TRT farms. Third, the calculated energy content of the supplements did not differ by treatment, nor by week, nor by their interaction. And finally, the CON supplements contained a much higher proportion of soluble protein (as percentage of CP) compared with the TRT supplement, particularly during the experimental period. Together, these observations support the idea that TRT cows were consuming a higher $\mathrm{CP}$ amount, including a higher rumen undegradable protein intake, during the experimental period, which could have supported the higher milk performance observed in the TRT group. Additionally, it is important to note that other nutrient fractions, such as aNDFom and ADF, were higher in the TRT supplement compared with the CON supplement. These fractions could have influenced rumen fermentation and ultimately supported more microbial protein synthesis and energetic substrate uptake, either of which would likely result in higher milk yield. With this context in mind, outcomes and observations from the current trial can help inform future research and farm management.

\section{Animal Measurements and Nutritive Composition}

Throughout the study, the mean BCS of treatment groups (Table 1; range: $2.56-2.79 \pm 0.2$ ) was at the lower end of the industry-recommended BCS range of 2.75 to 3.0 for cows at approximately 200 DIM (Wildman et al., 1982; Roche et al., 2007). Although little published research has outlined expected BCS ranges

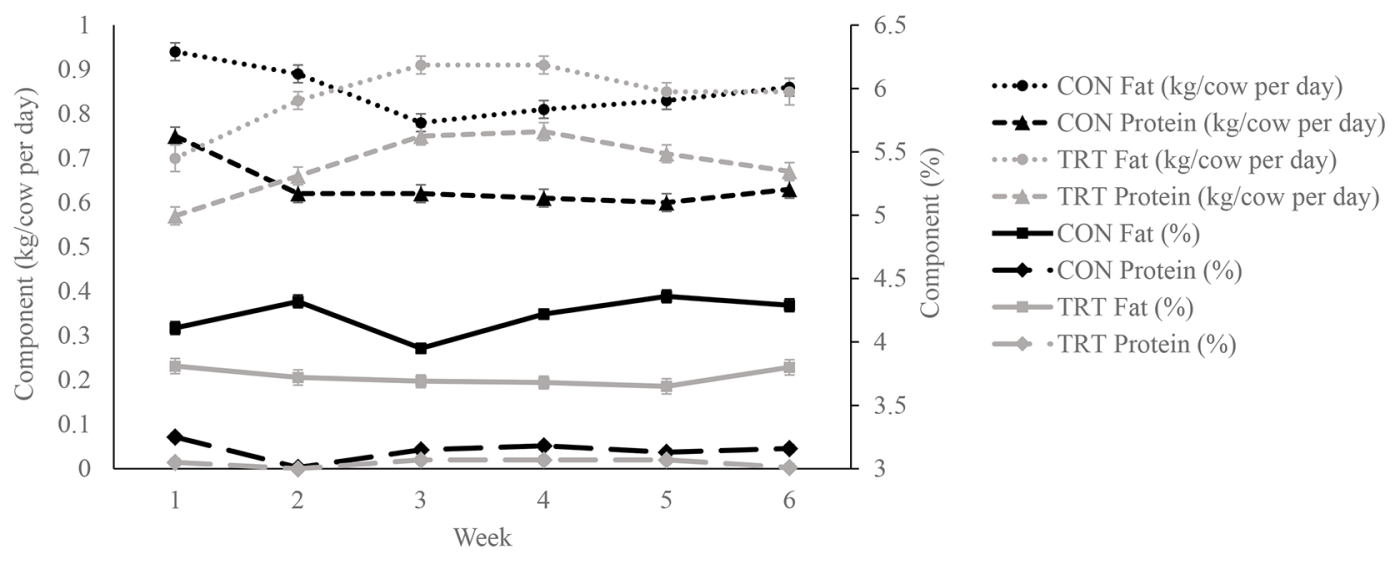

Figure 2. Mean weekly milk protein (percent and $\mathrm{kg} /$ cow per day) and milk fat (percent and $\mathrm{kg} /$ cow per day; $\pm \mathrm{SE}$ ) of 6 Vermont organic dairy farms while on their normal feeding strategies for 6 wk (CON, 3 farms) or while on their normal feeding strategies for wk 1 and 2 and offered a modified supplement for wk 3 through 6 (TRT, 3 farms). Milk fat percentage was affected by group $(P<0.0001)$, week $(P<0.0001)$, and group $\times$ week $(P<0.0001)$. Milk protein percentage was affected by group $(P=0.05)$, week $(P<0.0001)$, and group $\times$ week $(P<0.0001)$. Milk fat yield was not affected by group $(P=0.66)$ or week $(P=0.11)$ but was affected by group $\times$ week $(P<0.0001)$. Milk protein yield was not affected by group $(P=0.06)$ but was affected by week $(P<0.0001)$ and group $\times$ week $(P<0.0001)$. 
Table 5. Estimated DMI and pasture measurements for 6 Vermont organic dairy farms while on their normal feeding strategies for 6 wk (CON, 3 farms) or while on their normal feeding strategies for wk 1 and 2 (baseline period), and offered a modified supplement for wk 3 through 6 (TRT, 3 farms; experimental period) during the summer of 2018

\begin{tabular}{|c|c|c|c|c|c|c|}
\hline \multicolumn{2}{|c|}{ Parameter $^{1}$} & Treatment & $\begin{array}{l}\text { Disappearance } \\
\text { (kg of DM/ha) }\end{array}$ & $\begin{array}{c}\mathrm{DMI}^{2} \\
(\mathrm{~kg} \text { of } \mathrm{DM} / \mathrm{cow})\end{array}$ & $\begin{array}{c}\text { Post }^{3} \\
\text { (kg of DM/ha) }\end{array}$ & $\begin{array}{c}\mathrm{Pre}^{3} \\
(\mathrm{~kg} \text { of DM/ha) }\end{array}$ \\
\hline \multicolumn{2}{|c|}{ Baseline period } & $\mathrm{CON}$ & $866 \pm 350$ & $5.58 \pm 3.0$ & $2,654 \pm 213$ & $3,416 \pm 258$ \\
\hline \multicolumn{2}{|c|}{ Experimental period } & TRT & $1,003 \pm 421$ & $8.97 \pm 3.6$ & $3,007 \pm 213$ & $3,852 \pm 241$ \\
\hline \multirow[t]{9}{*}{ Week } & 1 & $\mathrm{CON}$ & $954 \pm 418$ & $5.88 \pm 3.8$ & $2,531 \pm 202$ & $3,337 \pm 202$ \\
\hline & & TRT & $1,790 \pm 418$ & $15.80 \pm 3.8$ & $2,867 \pm 202$ & $3,583 \pm 202$ \\
\hline & 3 & $\mathrm{CON}$ & $1,099 \pm 498$ & $7.00 \pm 4.8$ & $2,800 \pm 202$ & $3,628 \pm 269$ \\
\hline & & TRT & $1,398 \pm 454$ & $13.30 \pm 4.4$ & $3,024 \pm 202$ & $4,121 \pm 246$ \\
\hline & 4 & $\mathrm{CON}$ & $893 \pm 285$ & $6.40 \pm 2.2$ & $3,113 \pm 112$ & $3,561 \pm 202$ \\
\hline & & TRT & $778 \pm 285$ & $6.50 \pm 2.2$ & $2,956 \pm 134$ & $3,539 \pm 202$ \\
\hline & 5 & $\mathrm{CON}$ & $967 \pm 327$ & $7.19 \pm 3.0$ & $2,643 \pm 291$ & $3,494 \pm 224$ \\
\hline & & TRT & $932 \pm 401$ & $7.97 \pm 3.6$ & $2,979 \pm 358$ & $3,964 \pm 269$ \\
\hline & 6 & $\mathrm{CON}$ & $1,126 \pm 908$ & $9.19 \pm 4.2$ & $2,800 \pm 157$ & $3,583 \pm 246$ \\
\hline
\end{tabular}

${ }^{1}$ Shown as mean \pm SE.

${ }^{2} \mathrm{DMI}=$ estimated pasture intake ( $\mathrm{kg}$ of $\mathrm{DM} /$ cow per day).

${ }^{3}$ Post $=$ postgrazing field $;$ pre $=$ pregrazing field.

for grazing cows in the US Northeast, Roche et al. (2007) reported similar mean BCS values $(2.52-2.85$ on 5-point scale) of Holstein-Friesian and Jersey cows under a pasture-based system in New Zealand. Because BCS is used as an indicator of the relative amount of body fat or energy reserves that are stored subcutaneously in individual animals, a low BCS suggests that the animal may not be consuming enough energy to

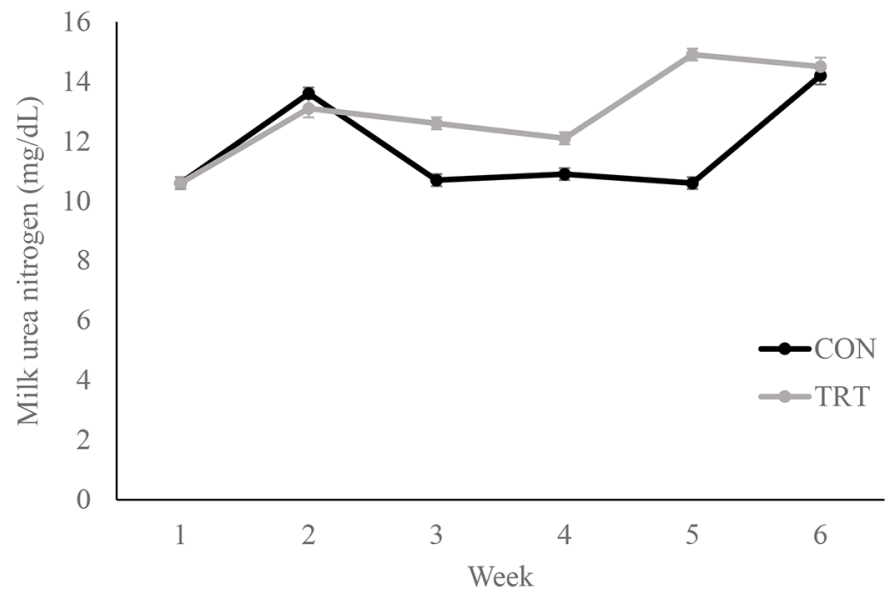

Figure 3. Mean weekly MUN concentrations $( \pm$ SE) of 6 Vermont organic dairy farms while on their normal feeding strategies for $6 \mathrm{wk}$ (CON, 3 farms) or while on their normal feeding strategies for wk 1 and 2 and offered a modified supplement for wk 3 through 6 (TRT, 3 farms). Milk urea nitrogen concentration was affected by group $(P<$ $0.0001)$, week $(P<0.0001)$, and group $\times$ week $(P<0.0001)$. meet individual energy demands (Roche et al., 2010). In terms of the shifts in BCS across time and treatment, our results support previous observations that increasing dietary $\mathrm{CP}$ does not necessarily result in BCS increases, as both CON and TRT cows had an increase in BCS from the baseline period to the end of the experimental period, and CON had a greater increase compared with TRT ( $2.61 \pm 0.03$ to $2.69 \pm 0.02$ vs. $2.65 \pm 0.03$ to $2.79 \pm 0.02$ BCS units, respectively). Law et al. (2009) observed similar results when feeding varying concentrations of $\mathrm{CP}$ to dairy cows $(114,144$, or $173 \mathrm{~g}$ of $\mathrm{CP} / \mathrm{kg}$ of $\mathrm{DM}$ ), with the mean BCS taken at 2 time points ranging from 2.53 to 2.66 units regardless of the dietary CP treatment. Rius et al. (2010) fed lactating dairy cows varying diets of high energy (addition of corn grain) and low energy (no corn grain), as well as high CP (soybean meal) and low CP (no soybean meal), and also observed no interaction between levels of $\mathrm{CP}$ and changes in BCS.

\section{Pasture Composition and Pasture DMI}

Pasture measurements were taken in pregrazing paddocks on individual farms weekly; however, weekly pregrazing paddocks changed on farms within the $6 \mathrm{wk}$ and is likely why we observed changes in pasture botanical and chemical composition. Pasture profiles were similar between the groups; however, fluctuations in the nutritive value of the pasture were identified. Of note, 
Ayers et al.: GRAZING CATTLE AND DIETARY CRUDE PROTEIN

1110
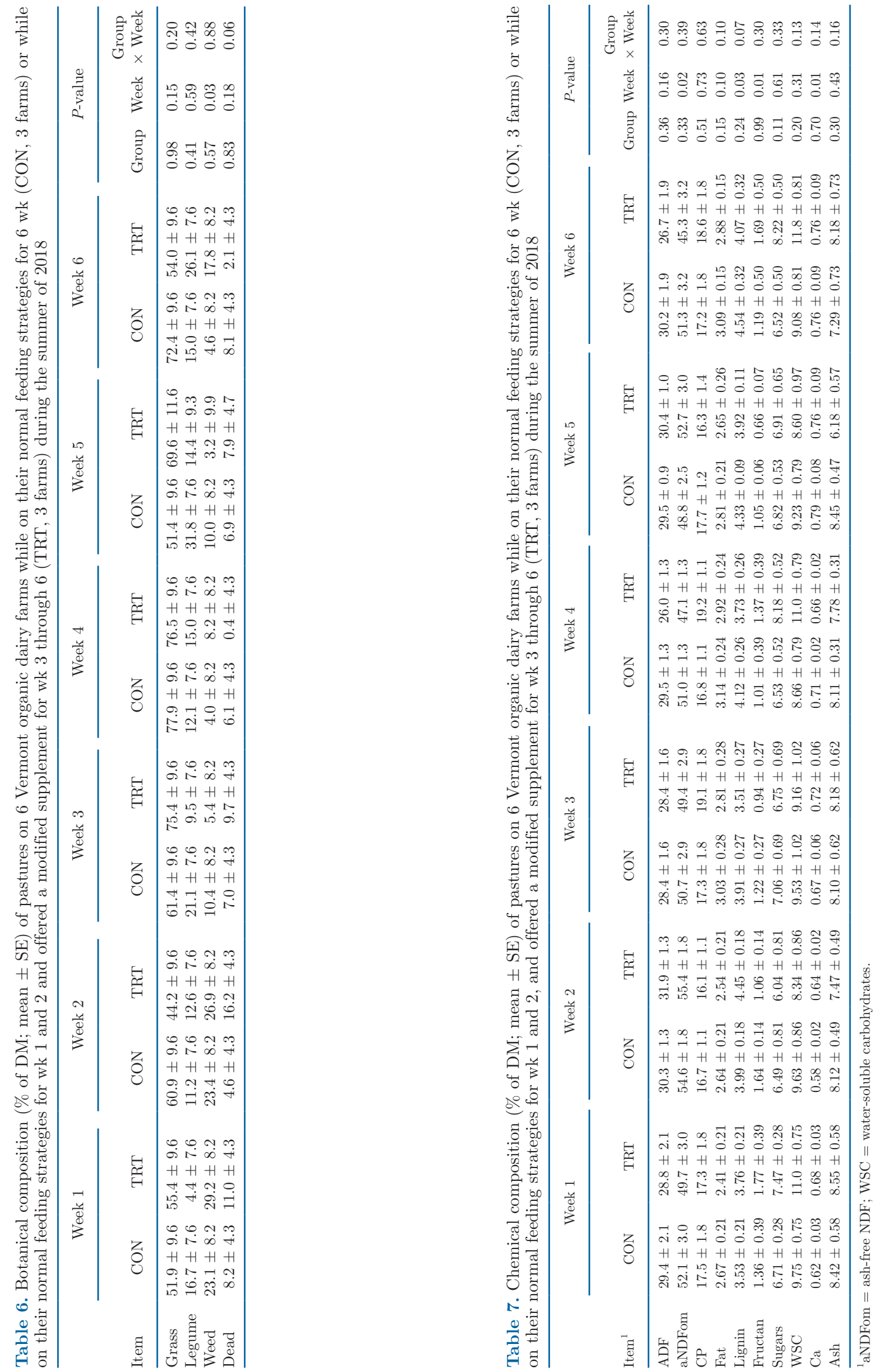
fructan and aNDFom concentrations both decreased in pastures from wk 1 to wk 6 (1.56 to $1.44 \%, 50.8$ to $48.3 \%$, respectively), whereas lignin and Ca concentrations increased from wk 1 to wk 6 (3.65 to $4.31 \%, 0.62$ to $0.75 \%$, respectively). Jensen et al. (2014) reported a similar trend in fructan concentrations across cool-season pastures throughout the grazing season; however, water-soluble carbohydrates and other sugars followed a similar trend, while no changes in these carbohydrates were observed in this present study. Pasture botanical composition and chemical composition were within range for pastures in the Northeast, and similar values have been observed in other studies (Brito et al., 2017).

Estimated DMI, pregrazing herbage mass, and postgrazing herbage mass did not differ between groups, week, or a.m. and p.m. grazing periods. These results agree with those of Vibart et al. (2017), who examined the influence of timing of allocation of fresh predominantly ryegrass pasture for dairy cows grazing in the a.m. or p.m. and observed no difference in DMI (12.7 vs. $12.9 \mathrm{~kg} / \mathrm{d}$ ) as determined by pre- and postgrazing measurements. This was a management strategy used by farms in this study, with a fraction of the farms (see Table 1 for grazing management protocols) using different paddocks for grazing in the morning versus grazing at night, with the intention of the higher-quality pastures being grazed at times when DMI is predicted to be higher for the grazing animals. It has been established that nutrient profiles have diurnal patterns, with a trend toward increased $\mathrm{CP}$ content in the a.m. and decreased CP content in the p.m. due to dilution resulting from increased water-soluble carbohydrates content and DM percentage (Delagarde et al., 2000; Shewmaker et al., 2006; Vibart et al., 2017). Ipharraguerre and Clark (2005) observed a decrease in DMI $(-0.5 \%, P<$ $0.05)$ among dairy cows supplemented with less than $15.9 \%$ or more than $18.0 \%$ dietary CP in the diet. In this study, the CP percentage fed to the CON group during the experimental period ranged from 13.4 to $15.8 \%$, whereas the TRT CP percentage ranged from 17.0 to $20.6 \%$, with no changes in estimated DMI in the experimental period or the baseline versus the experimental period.

\section{Effects on Milk Production and Composition}

Milk production for CON and TRT during the baseline period was similar; however, during the experimental period, the milk yield ( $\mathrm{kg} / \mathrm{cow}$ per day) of the CON group decreased, while the TRT group maintained milk production $(P<0.0001)$. Given that both the TRT and CON groups had a similar pasture nutrient intake and pasture DMI throughout both the baseline period and experimental period, this suggests that the response seen in milk yield from the TRT farms was likely due to the formulated supplement. Although estimated DMI did not differ in this study, milk yield differed across the TRT and CON groups, and a treatment by week interaction occurred, as milk yield from the CON group decreased from the baseline period throughout wk 6 (23.6 vs. $20.4 \mathrm{~kg}$ of milk per day, respectively), whereas TRT initially increased from baseline period to wk 4 (22.9 vs. $25.1 \mathrm{~kg}$ of milk per day, respectively). These results are similar to those observed by Olmos Colmenero and Broderick (2006), who determined that increasing the $\mathrm{CP}$ content from $13.5 \% \mathrm{CP}$ up to $16.5 \%$ increased milk yield by $2 \mathrm{~kg} / \mathrm{d}$, but feeding a diet containing greater than $16.5 \% \mathrm{CP}(17.9$ or $19.4 \% \mathrm{CP})$ did not increase milk yield compared with production from cows fed lower-CP diets. Our current study is in line with the upper limit of that inflection point, likely due to some of the ingredients used in the formulation of the supplement having higher $\mathrm{CP}$ concentrations than expected. The biology surrounding the increase in milk yield when feeding CP is likely rumen-related. Studies have shown that DMI and fiber digestibility increase when protein is increased in dairy cow diets due to an increase in microbial activity and available rumen-degradable protein (Oldham, 1984; Allen, 2000; Alstrup et al., 2014) and can increase endogenous urea nitrogen synthesis and recycling (Lapierre and Lobley, 2001; Reynolds and Kristensen, 2008; Mutsvangwa et al., 2016).

Other studies have observed higher milk fat and protein percentages in cows receiving high levels of dietary CP content (Veerkamp et al., 1994; Law et al., 2009; Alstrup et al., 2014). Although TRT cows in the current study produced milk with lower fat and protein percentage, the yields $(\mathrm{kg} / \mathrm{cow}$ per day) of these components were not affected by group. Interestingly, a group by week interaction affecting fat and protein yields created a larger differential production across the TRT and CON groups (with TRT having the higher yields) during the earlier weeks of the experimental period. Because the milk fat and protein percentages were relatively consistent within group across week, the higher milk yield in the TRT group is the primary driving factor creating the component yields from this treatment group.

A repercussion of the higher-CP supplement is its influence on MUN concentrations. The MUN concentrations of the farms included in this study ranged from 5.36 to $14.7 \mathrm{mg} / \mathrm{dL}$ during the previous summer grazing season; however, both TRT and CON had higher MUN concentrations in the baseline period of this experiment compared with the previous season (11.9 and $12.1 \mathrm{mg} / \mathrm{dL}$, respectively). The MUN concentrations for the duration of this trial were higher for TRT 
than for CON (13.0 vs. $11.8 \mathrm{mg} / \mathrm{dL}$, respectively), indicating an increase in rumen ammonia and endogenous ureagenesis (Mutsvangwa et al., 2016). This is in agreement with findings reported by Groff and $\mathrm{Wu}$ (2005) and Alstrup et al. (2014), who also observed an increase in MUN concentrations when studying the effects of dietary CP concentrations. Interestingly, MUN concentrations increased from wk 1 to wk 6 in both CON and TRT groups (10.6 to $14.2 \mathrm{mg} / \mathrm{dL}$ and 10.6 to $14.5 \mathrm{mg} / \mathrm{dL}$, respectively). The increase of MUN concentrations across the grazing season has been observed in other studies and has been attributed to seasonal variations in energy and protein concentrations from pasture (Moller et al., 1993; Godden et al., 2001). The higher MUN concentrations ( $>14 \mathrm{mg} / \mathrm{dL})$ in samples collected during wk 5 (TRT group only) and 6 (both the CON and TRT groups) are indicative of a potential dietary excess of protein. The observation that MUN concentrations increased across both TRT and CON groups during this latter part of the trial was not a reflection of shifts in the $\mathrm{CP}$ (as percentage of DM) of the pasture or supplement, nor did notable changes in the botanical composition occur (particularly in the grass and legume proportions) that could account for this increase in MUN. However, increases in DMI that could not be statistically differentiated using the described pasture and supplement intake measurement methods may be the root cause. Additionally, although changes in pasture energy and protein concentrations were not observed in this study, the weekly samples collected throughout the 6 wk were from different paddocks in various locations throughout the farm and may not have reflected the botanical composition or nutrient profile the animals received throughout the entire week. Another explanation may be that the profile of grasses or legumes shifted. Carrillo-Hernández et al. (2020) recently reported a significant influence of grass species on MUN despite a similar chemical profile, and botanical identification down to the species level was not performed in the present trial. A third explanation may be shifts in grazing behavior. Individual MUN concentrations usually peak approximately $6 \mathrm{~h}$ after feeding (Ferdinand et al., 2000), and we did not record grazing behavior or patterns. As we know that many farms shift to night grazing when temperatures increase, this could have resulted in a shift in MUN. Despite these concentrations being higher than the preferred range, these MUN concentrations are still reported to be safe, with no adverse effects on milk production or reproductive performance (Powell et al., 2011). Calculation of potential urine nitrogen losses ( $\mathrm{g}$ of urinary excretion of nitrogen $=\mathrm{kg}$ of $\mathrm{BW} \times 0.0259 \times \mathrm{MUN} \mathrm{mg} / \mathrm{dL}$; Kauffman and St-Pierre, 2001) suggests a difference of $40 \mathrm{~g}$ of urine nitrogen loss per day between the base- line period (wk $1+2$ mean $\mathrm{MUN}=12.0 \mathrm{mg} / \mathrm{dL}$ ) and wk 6 (mean MUN $=14.4 \mathrm{mg} / \mathrm{dL}$ ) across both groups (estimated for a $650-\mathrm{kg}$ Holstein). The summative loss of this additional nitrogen throughout the summer at the herd level needs to be further assessed for environmental and financial impacts in the context of nutrient cycling and productivity.

\section{CONCLUSIONS}

The results herein indicate that an increase in $\mathrm{CP}$ content of the dietary supplements fed during the summer grazing period in the northeastern United States can provide additional $\mathrm{N}$ that may be limited from pasture during the grazing season, particularly during the warmer summer months. Cows in both groups had similar DMI and nutritive value in pastures, yet milk yield was maintained throughout the 6 wk of the study for animals receiving the higher levels of $\mathrm{CP}$ content compared with a decrease in milk yield with animals in the CON group. Fat and protein percentages were higher in the CON than in the TRT group throughout the duration of this study. In conclusion, increase of dietary $\mathrm{CP}$ is a viable option to maintain milk and, at times, slightly increase production for organic grazing cattle in which dietary $\mathrm{CP}$ from pasture may be limited. However, additional research is necessary to further assess the effects of the different dietary protein fractions on grazing cow performance, as several factors in the current trial suggest that rumen undegradable protein may be the most critical fraction.

\section{ACKNOWLEDGMENTS}

The authors thank all participating farms for their engagement and support throughout the experiment. The authors also thank C. Kadis and H. Malcomson (University of Vermont, Burlington) for their assistance during the sample collection process. Funding for this project was provided by the US Department of Agriculture, National Institute of Food and Agriculture (Washington, DC) Organic Agriculture Research and Extension Initiative (OREI), project number 201507409. The authors have not stated any conflicts of interest.

\section{REFERENCES}

Aguilar, M., M. D. Hanigan, H. A. Tucker, B. L. Jones, S. K. Garbade, M. L. McGilliard, C. C. Stallings, K. F. Knowlton, and R. E. James. 2012. Cow and herd variation in milk urea nitrogen concentrations in lactating dairy cattle. J. Dairy Sci. 95:7261-7268. https: //doi.org/10.3168/jds.2012-5582.

Allen, M. S. 2000. Effects of diet on short-term regulation of feed intake by lactating dairy cattle. J. Dairy Sci. 83:1598-1624. https:// doi.org/10.3168/jds.S0022-0302(00)75030-2. 
Alstrup, L., M. R. Weisbjerg, L. Hymøller, M. K. Larsen, P. Lund, and M. O. Nielsen. 2014. Milk production response to varying protein supply is independent of forage digestibility in dairy cows. J. Dairy Sci. 97:4412-4422. https://doi.org/10.3168/jds.2013-7585.

Ayers, A. 2020 Feeding strategies for gazing organic dairy cows and the impact on milk production. MS thesis. Department of Animal Science, University of Vermont.

Bargo, F., L. D. Muller, E. S. Kolver, and J. E. Delahoy. 2003. Invited Review: Production and digestion of supplemented dairy cows on pasture. J. Dairy Sci. 86:1-42. https://doi.org/10.3168/jds.S0022 -0302(03)73581-4.

Brito, A. F., K. J. Soder, P. Y. Chouinard, S. F. Reis, S. Ross, M. D. Rubano, and M. D. Casler. 2017. Production performance and milk fatty acid profile in grazing dairy cows offered ground corn or liquid molasses as the sole supplemental nonstructural carbohydrate source. J. Dairy Sci. 100:8146-8160. https://doi.org/10 .3168/jds.2017-12618.

Carrillo-Hernández, F., F. López-González, J. G. Estrada-Flores, and C. M. Arriaga-Jordán. 2020. Milk production and estimated enteric methane emission from cows grazing ryegrass pastures in small-scale diary systems in Mexico. Trop. Anim. Health Prod. 52:3609-3619. https://doi.org/10.1007/s11250-020-02398-0.

Correa-Luna, M., D. Donaghy, P. Kemp, M. Schutz, and N. LópezVillalobos. 2020. Efficiency of crude protein utilisation in grazing dairy cows: A case study comparing two production systems differing in intensification level in New Zealand. Animals (Basel) 10:1036. https://doi.org/10.3390/ani10061036.

Delagarde, R., J. L. Peyraud, L. Delaby, and P. Faverdin. 2000. Vertical distribution of biomass, chemical composition and pepsincellulase digestibility in perennial ryegrass sward: Interaction with month of year, regrowth age, and time of day. Anim. Feed Sci. Technol. 84:49-68. https://doi.org/10.1016/S0377-8401(00)00114 -0 .

Ferdinand, E. E., J. E. Shirley, M. J. Meyer, A. F. Park, M. J. VanBaale, and E. C. Titgemeyer. 2000. Relationship among concentrations of milk urea nitrogen and plasma urea nitrogen and feeding time. Kansas Agricultural Experiment Station Research Reports. https://doi.org/10.4148/2378-5977.3197.

Godden, S. M., K. D. Lissemore, D. F. Kelton, K. E. Leslie, J. S. Walton, and J. H. Lumsden. 2001. Relationships between milk urea concentrations and nutritional management, production, and economic variables in Ontario dairy herds. J. Dairy Sci. 84:1128-1139. https://doi.org/10.3168/jds.S0022-0302(01)74573-0.

Groff, E. B., and Z. Wu. 2005. Milk production and nitrogen excretion of dairy cows fed different amounts of protein and varying of alfalfa and corn silage. J. Dairy Sci. 88:3619-3632. https://doi.org/ 10.3168/jds.S0022-0302(05)73047-2.

Hafla, A. N., K. J. Soder, A. F. Brito, R. Kersbergen, F. Benson, H. Darby, M. Rubano, and S. R. Reis. 2016. Case study: Feeding strategy and pasture quality relative to nutrient requirements of dairy cows in the northeastern United States. Prof. Anim. Sci. 32:523-530. https://doi.org/10.15232/pas.2015-01500.

Hafla, A. N., K. J. Soder, M. Hautau, M. D. Rubano, B. Moyer, and R. Stout. 2014. Case Study: Dairies using self-described ultra-high stocking density grazing in Pennsylvania and New York. Prof. Anim. Sci. 30:366-374. https://doi.org/10.15232/S1080 -7446(15)30129-7.

Hardie, C. A., M. Wattiaux, M. Dutreuil, R. Gildersleeve, N. S. Keuler, and V. E. Cabrera. 2014. Feeding strategies on certified organic dairy farms in Wisconsin and their effect on milk production and income over feed costs. J. Dairy Sci. 97:4612-4623. https://doi .org/10.3168/jds.2013-7763.

Higgs, R. J., A. J. Sheahan, K. Mandok, M. E. Van Amburgh, and J. R. Roche. 2013. The effect of starch-, fiber-, or sugar-based supplements on nitrogen utilization in grazing dairy cows. J. Dairy Sci. 96:3857-3866. https://doi.org/10.3168/jds.2012-6117.

Hoogendoorn, C. J., C. W. Holmes, and A. C. P. Chu. 1992. Some effects of herbage composition, as influenced by previous grazing management, on milk production by cows grazing ryegrass/ white clover pastures. 2. Milk production in late spring/summer: Effects of grazing intensity during the preceding spring period.
Grass Forage Sci. 47:316-325. https://doi.org/10.1111/j.1365-2494 .1992.tb02277.x.

Ipharraguerre, I. R., and J. H. Clark. 2005. Varying protein and starch in the diet of dairy cows. II. Effects on performance and nitrogen utilization for milk production. J. Dairy Sci. 88:2556-2570. https: //doi.org/10.3168/jds.S0022-0302(05)72932-5.

Jensen, K. B., P. Harrison, N. J. Chatterton, B. S. Bushman, and J. E. Creech. 2014. Seasonal trends in nonstructural carbohydrates in cool- and warm-season grasses. Crop Sci. 54:2328-2340. https:/ /doi.org/10.2135/cropsci2013.07.0465.

Kauffman, A. J., and N. R. St-Pierre. 2001. The relationship of milk urea nitrogen to urine nitrogen excretion in Holstein and Jersey cows. J. Dairy Sci. 84:2284-2294.

Khalili, H., and A. Sairanen. 2000. Effect of concentrate type on rumen fermentation and milk production of cows at pasture. Anim. Feed Sci. Technol. 84:199-212. https://doi.org/10.1016/S0377 -8401(00)00130-9.

Kohn, R. A., K. F. Kalscheur, and E. Russek-Cohen. 2002. Evaluation of models to estimate urinary nitrogen and expected milk urea nitrogen. J. Dairy Sci. 85:227-233. https://doi.org/10.3168/ jds.S0022-0302(02)74071-X.

Lapierre, H., and G. E. Lobley. 2001. Nitrogen recycling in the ruminant: A review. J. Dairy Sci. 84:E223-E236. https://doi.org/10 .3168/jds.S0022-0302(01)70222-6.

Law, R. A., F. J. Young, D. C. Patterson, D. J. Kilpatrick, A. R. G. Wylie, and C. S. Mayne. 2009. Effect of dietary protein content on animal production and blood metabolites of dairy cows during lactation. J. Dairy Sci. 92:1001-1012. https://doi.org/10.3168/jds 2008-1155.

Liang, D., F. Sun, M. A. Wattiaux, V. E. Cabrera, J. L. Hedtcke, and E. M. Silva. 2017. Effect of feeding strategies and cropping systems on greenhouse gas emission from Wisconsin certified organic dairy farms. J. Dairy Sci. 100:5957-5973. https://doi.org/10.3168/ jds.2016-11909.

Macoon, B., L. E. Sollenberger, C. R. Staples, K. M. Portier, J. H. Fike, and J. E. Moore. 2011. Grazing management and supplementation effects on forage and dairy cow performance on coolseason pastures in the southeastern United States. J. Dairy Sci. 94:3949-3959. https://doi.org/10.3168/jds.2010-3947.

Mogensen, L., P. Lund, T. Kristensen, and M. R. Weisbjerg. 2008. Effects of toasting blue lupins, soybeans or barley as supplement for high-yielding, organic dairy cows fed grass-clover silage ad libitum. Livest. Sci. 115:249-257. https://doi.org/10.1016/j.livsci.2007.08 .011 .

Moller, S., C. Matthew, and G. F. Wilson. 1993. Pasture protein and soluble carbohydrate levels in spring dairy pasture and associations with cow performance. Proc. N.Z. Soc. Anim. Prod. 54:83-86.

Mutsvangwa, T., K. L. Davies, J. J. McKinnon, and D. A. Christensen. 2016. Effects of dietary crude protein and rumen-degradable protein concentrations on urea recycling, nitrogen balance, omasal nutrient flow, and milk production in dairy cows. J. Dairy Sci. 99:6298-6310. https://doi.org/10.3168/jds.2016-10917.

Nikkhah, A. 2012. Barley grain for ruminants: a global treasure of tragedy. J. Anim. Sci. Biotechnol. 3:22. https://doi.org/10.1186/ 2049-1891-3-22.

NOAA, National Centers for Environmental Information. 2019. Climate at a glance: County time series. Retrieved May 18, 2021. http://www.ncdc.noaa.gov/cag/.

Nousiainen, J., K. J. Shingfield, and P. Huhtanen. 2004. Evaluation of milk urea nitrogen as a diagnostic of protein feeding. J. Dairy Sci. 87:386-398. https://doi.org/10.3168/jds.S0022-0302(04)73178-1.

Oldham, J. D. 1984. Protein-energy interrelationships in dairy cows. J. Dairy Sci. 67:1090-1114. https://doi.org/10.3168/jds.S0022 $-0302(84) 81410-1$

Olmos Colmenero, J. J., and G. A. Broderick. 2006. Effect of dietary crude protein concentration on milk production and nitrogen utilization in lactating dairy cows. J. Dairy Sci. 89:1704-1712. https:/ /doi.org/10.3168/jds.S0022-0302(06)72238-X.

Oltner, R., and H. Wiktorsson. 1983. Urea concentrations in milk and blood as influenced by feeding varying amounts of protein and en- 
ergy to dairy cows. Livest. Prod. Sci. 10:457-467. https://doi.org/ 10.1016/0301-6226(83)90073-8.

Powell, J. M., C. A. Rotz, and M. A. Wattiaux. 2014. Potential use of milk urea nitrogen to abate atmospheric nitrogen emissions from Wisconsin dairy farms. J. Environ. Qual. 43:1169-1175. https:// doi.org/10.2134/jeq2013.09.0375.

Powell, J. M., M. A. Wattiaux, and G. A. Broderick. 2011. Short communication: Evaluation of milk urea nitrogen as a management tool to reduce ammonia emissions from dairy farms. J. Dairy Sci. 94:4690-4694. https://doi.org/10.3168/jds.2011-4476.

Reynolds, C. K., and N. B. Kristensen. 2008. Nitrogen recycling through the gut and the nitrogen economy of ruminants: An asynchronous symbiosis. J. Anim. Sci. 86(Suppl. 14):E293-E305. https: //doi.org/10.2527/jas.2007-0475.

Ritz, K. E., B. J. Heins, R. Moon, C. Sheaffer, and S. L. Weyers. 2020. Forage yield and nutritive value of cool-season and warmseason forages for grazing organic dairy cattle. Agronomy (Basel) 10:1963. https://doi.org/10.3390/agronomy10121963.

Rius, A. G., M. L. McGilliard, C. A. Umberger, and M. D. Hanigan. 2010. Interactions of energy and predicted metabolizable protein in determining nitrogen efficiency in the lactating dairy cow. J. Dairy Sci. 93:2034-2043. https://doi.org/10.3168/jds.2008-1777.

Roche, J. R., J. K. Kay, C. V. C. Phyn, S. Meier, J. M. Lee, and C. R. Burke. 2010. Dietary structural to nonfiber carbohydrate concentration during the transition period in grazing dairy cows. J. Dairy Sci. 93:3671-3683. https://doi.org/10.3168/jds.2009-2868.

Roche, J. R., J. M. Lee, K. A. Macdonald, and D. P. Berry. 2007. Relationship among body condition score, body weight, and milk production variables in pasture-based dairy cows. J. Dairy Sci. 90:3802-3815. https://doi.org/10.3168/jds.2006-740.

Shewmaker, G. E., H. F. Mayland, C. A. Roberts, P. A. Harrison, N. J. Chatterton, and D. A. Sleper. 2006. Daily carbohydrate accumulation in eight tall fescue cultivars. Grass and Forage Sci. 61:413-421. https://doi.org/10.1111/j.1365-2494.2006.00550.x.

Soder, K. J., K. Hoffman, L. E. Chase, and M. D. Rubano. 2012. Case study: Molasses as the primary energy supplement on an organic grazing dairy farm. Prof. Anim. Sci. 28:234-243. https://doi.org/ 10.15232/S1080-7446(15)30345-4.

Soder, K. J., M. A. Sanderson, J. L. Stack, and L. D. Muller. 2006. Intake and performance of lactating cows grazing diverse forage mixtures. J. Dairy Sci. 89:2158-2167. https://doi.org/10.3168/jds .S0022-0302(06)72286-X.

Totty, V. K., S. L. Greenwood, R. H. Bryant, and G. R. Edwards. 2013. Nitrogen partitioning and milk production of dairy cows grazing simple and diverse pastures. J. Dairy Sci. 96:141-149. https://doi.org/10.3168/jds.2012-5504.

Trevaskis, L. M., and W. J. Fulkerson. 1999. The relationship between various animal and management factors and milk urea, and its association with reproductive performance of dairy cows grazing pasture. Livest. Prod. Sci. 57:255-265. https://doi.org/10.1016/ S0301-6226(98)00174-2.

USDA AMS (US Department of Agriculture, Agriculture Marketing Service). 2010a. National Organic Program: Access to Pasture (Livestock). 7 CFR Part 205.239. Accessed Oct. 26, 2021. https: //www.ams.usda.gov/rules-regulations/access-pasture-organic -livestock.

USDA AMS (US Department of Agriculture, Agriculture Marketing Service). 2010b. National Organic Program: Allowed and prohibited substances, methods, and ingredients in organic production and handling. 7 CFR Part 205.105. Accessed Oct. 26, 2021. https: //www.ams.usda.gov/rules-regulations/organic/national-list.

USDA ERS (US Department of Agriculture-Economic Research Service) 2002. Recent Growth Patterns in the U.S. Organic Foods Market. Accessed Oct. 26, 2021. https://www.ers.usda.gov/ publications/pub-details/?pubid $=42456$.

USDA NASS (US Department of Agriculture-National Agricultural Statistics Service). 2017. Certified Organic Survey. Accessed Oct. 26, 2021. https://downloads.usda.library.cornell.edu/usda-esmis/ files/zg64tk92g/70795b52w/4m90dz33q/OrganicProduction-09-20 -2017_correction.pdf.

Veerkamp, R. F., G. Simm, and J. D. Oldham. 1994. Effects of interaction between genotype and feeding system on milk production, feed intake, efficiency and body tissue mobilization in dairy cows. Livest. Prod. Sci. 39:229-241. https://doi.org/10.1016/0301 -6226(94)90202-X.

Vibart, R. E., M. Tavendale, D. Otter, B. H. Schwendel, K. Lowe, P. Gregorini, and D. Pacheco. 2017. Milk production and composition, nitrogen utilization, and grazing behavior of late-lactation dairy cows affected by time of allocation of a fresh strip of pasture. J. Dairy Sci. 100:5305-5318. https://doi.org/10.3168/jds.2016 $-12413$.

Wildman, E. E., G. M. Jones, P. E. Wagner, R. L. Boman, H. F, Troutt Jr., and T. N. Lesch. 1982. A dairy cow body condition scoring system and its relationship to selected production characteristics. J. Dairy Sci. 65:495-501. https://doi.org/10.3168/jds .S0022-0302(82)82223-6.

\section{ORCIDS}

S. E. Ziegler @ https://orcid.org/0000-0003-4103-3274

H. M. Darby @ https://orcid.org/0000-0003-4553-1684

J. P. Alvez $\odot$ https://orcid.org/0000-0002-9661-6525

J. Kraft $\odot$ https://orcid.org/0000-0003-3445-2710

S. L. Greenwood ๑ https://orcid.org/0000-0003-0654-6103 